\title{
TAXATION OF HOLDING COMPANIES IN THE NETHERLANDS: A SOUTH AFRICAN OBSERVATION
}

\author{
Thabo Legwaila \\ Bluris LLB LLM PG Dip Tax LLM LLD \\ Extraordinary Lecturer \\ Department of Mercantile Law \\ University of Pretoria
}

\section{SUMMARY}

The South African government has expressed an intention to market itself as a gateway to investment in Africa. This will be achieved inter alia by redesigning certain aspects of the tax laws in order to encourage investment into South Africa in the form of headquarter companies as a special kind of holding companies. The Netherlands has over time adjusted its tax regime to achieve the same goal, viz, to attract holding companies for investment into European countries and globally. Specifically, the Dutch participation exemption and the advance-tax ruling system have been hailed as the key tax instruments that are instrumental in attracting foreign residents to set up holding companies in the Netherlands. Furthermore, the intentional absence of various tax instruments such as controlled foreign-company provisions and exchange-control regulations further enhance the Netherlands' suitability to host holding companies. In light of the South African government's intentions to attract holding companies, it is important to study the Dutch system applicable to holding companies to see what attributes, if any, South Africa could also adopt.

\section{INTRODUCTION}

The South African National Treasury announced in the 2010 Budget review, ${ }^{1}$ and reiterated in the 2011 Budget Review ${ }^{2}$ that it intends to promote South Africa as a gateway to investment into Africa. In pursuance of this goal, the National Treasury is examining the South African corporate and business framework as well as exchange control and corporate-tax laws, to determine if the corporate, business, legal and tax environment could stifle the ability of South Africa to serve as a base through which investors could access investment opportunities into Africa. ${ }^{3}$ Furthermore, legislation has been

National Treasury Budget Review (2010) 78-79.

National Treasury Budget Review (2011) 73.

See National Treasury Budget Review 78-79. See also Lermer "2010 Budget Attracts SA Based Headquarter Companies" Moneyweb http://www.moneyweb.co.za/mw/view/mw/en/ page302588? oid=347864\&sn=2009\%20Detail (accessed 2011-04-01); and Legwaila "The Tax Treatment of Holding Companies in Mauritius: Lessons for South Africa" 2011 South African Mercantile LJ 1. 
amended in order to remove any identified impediments to attracting headquarter companies to South Africa. ${ }^{4}$

One of the methods in which South Africa could be used to access investment into Africa is by investors centralizing finances, co-ordination and administration of their African investments in South Africa. This would be achieved by setting up of a holding company in the form of an international headquarter company ${ }^{5}$ in South Africa.

The Netherlands has been very successful in attracting international business, mainly in the form of holding companies from all over the world, including within the European Union. This is largely due to the tax regime that it applies to holding, which contains tax instruments that ease the tax burden for holding companies. ${ }^{6}$ The Netherlands is ranked 26 out of 181 economies in terms of ease of doing business. ${ }^{7}$ The Dutch economy has changed significantly in the last 20 years mainly due to its perspectives on international business and open-market policies.

The ability to route investment from all over the world through the holding companies located in a country is the attribute that the South African government seeks to achieve by making South Africa a financial centre for Africa. Against this backdrop, it becomes important to study the Dutch system as far as instruments that are used to attract holding companies are concerned to determine whether they can be used to lure investors to South African shores. ${ }^{9}$ This article examines the main tax instruments available in the Dutch tax system that make the Netherlands a successful holdingcompany jurisdiction, and determines whether they can be suitably adopted by South Africa for the same purpose.

\section{DUTCH HOLDING COMPANY}

The Dutch civil, corporate and tax laws do not contain the concept of a holding company as such. Thus there are no provisions in these legal

\footnotetext{
See Taxation Laws Amendment Act 7 of 2010.

International headquarter companies are companies that are formed where multinational groups of companies have significant economic interests in a region which is distant from its head office to oversee and co-ordinate the group's business interests in a particular region. "Such centres will usually provide the full range of administrative and management functions associated with a head office; for example, treasury and tax management, internal audit, public relations, market research and marketing, insurance and accounting" Ogley Principles of International Tax: A Multinational Perspective (1993) 137.

6 See ABAB Accountants, Tax Consultants and Lawyers Doing Business in the Netherlands http://www.abab.nl/downloads/DOINGBUSINESSEN.pdf (accessed 2011-05-25).

7 See World Bank Doing Business 2009 - Country Profile for Netherlands http://www. doingbusiness.org/Documents/CountryProfiles/NLD.pdf (accessed 2011-05-25).

8 Koninkrijk der Nederlanden Doing Business in the Netherlands http://www.netherlandsembassy.org/printerfriendly.asp?articleref=AR00002251EN (accessed 2011-05-25).

9 See Legwaila "Tax Reasons for Establishing a Headquarter Company" 2011 32(1) Obiter 126.
} 
instruments that specifically provide for Dutch holding companies. ${ }^{10}$ Accordingly, a holding company is subject to normal company law. ${ }^{11}$

Dutch corporate law comprises a closed system of legal entities. In terms of this system, no new types of legal entities can be created by the will of the parties. ${ }^{12}$ The legal entities provided for in the Dutch Civil Code are the association, co-operative, mutual-insurance society, limited-liability company, public company and the foundation. A limited-liability company is a closed company with limited liability referred to in Dutch as Besloten Vennootschap met beperkte aansprakelijkheid and abbreviated as "BV". ${ }^{13}$

For tax purposes, a Dutch holding company is an ordinary company. A European company with its seat in the Netherlands can also be used as a Dutch holding company. ${ }^{14}$ As with any other company, the Dutch holding company is subject to the normal tax system and files the same tax returns as any other corporate taxpayer. ${ }^{15}$

The provisions in the Dutch Civil Code regarding the BV are currently being reviewed. ${ }^{16}$ The objective of the review is to create a more flexible legal form. A preliminary text of a legislative proposal was published by the Dutch Ministry of Justice for consultation in three separate sections in 2005 and 2006. These have led to a number of reactions from various experts on corporate law.

The legislative amendments relate to the structuring of the BV from a company-law perspective and not the tax status of the BV. As a result, the changes are not expected to affect the tax treatment of the BV and therefore would not affect the context in which the BV is used as a holding company for tax purposes. Owing to their specific functions and the rarity of their use, the tax implications where the co-operative and the CV are used as holding companies will not be further discussed here, unless if absolutely necessary or relevant.

10 Lambooij and Portengen Netherlands - Holding Companies (2008) par 1.1.1.1 http://online2.ibfd.org/collections/hold/html/hold_nl.html (accessed 2011-07-19).

See Book 2 of the Dutch Civil Code.

12 Lambooij and Portengen Netherlands - Holding Companies par 1.1.1.1.

13 See http://www.tax-consultants-international.com/read/How_to_incorporate_a_BV (accessed 2011-08-01), where it is further stated that "[i]n comparison to other jurisdictions the BV can be seen as the equivalent of the German ' $\mathrm{GmbH}$ ', the American 'LLC', or the English 'Ltd'. The BV has legal personality and it has an equity divided into shares. A BV can only have registered shares, and shares are always not freely transferable. The shareholders of a BV are in general not personally liable for acts performed in the name or on behalf of the $\mathrm{BV}$, nor can they be compelled to make more funds available than that part of the capital for which they have subscribed."

14 Lambooij and Portengen Netherlands - Holding Companies par 1.1.1.1. Incorporating a holding company in the form of a European company with a seat in the Netherlands is not a commonly used structure.

15 Lambooij and Peelen "The Netherlands Holding Company - Past and Present" 2006 Bulletin for International Taxation 4.1. See also Netherland Holding Company Overview http://www.ocra.com/solutions/eu_holding/Netherlands.asp (accessed 2011-07-06).

16 See Fernández and Olffen Regulation and application of LLP and LLC (2007) 1-3 http://www.wodc.nl/images/1423_summary_tcm44-81289.pdf (accessed 2011-06-08). 


\section{THE DUTCH CORPORATE-TAX SYSTEM}

\section{General}

The Netherlands tax system is based on a number of laws some of which date back many years. ${ }^{17}$ In the Netherlands, corporate income tax is levied on both resident and non-resident companies. Resident companies are taxable on their worldwide income and non-resident companies, primarily branch offices of foreign companies doing business in the Netherlands, are taxable only on income derived from a source within the Netherlands. Resident companies are companies incorporated under the Dutch Civil Law $^{18}$ and foreign incorporated companies that are effectively managed in the Netherlands.

\section{Corporate income tax}

Dutch companies are subject to a corporate income tax at the rate of $25.5 \%{ }^{20}$ The standard tax year is the calendar year. However, a company is allowed to use its financial year as its tax year. As opposed to common practice, the Netherlands is one of the few countries where, in calculating taxable income, no distinction is made between ordinary income and capital gains. Taxable profits are calculated in euro, although a corporation can elect to determine its taxable profits in its functional currency. ${ }^{21}$

Non-resident corporates and individuals are subject to corporate or individual income tax, respectively, at the normal rates applicable to Dutch residents. This liability arises if the shareholder has a substantial interest in the Netherlands holding company and such interest cannot be allocated to the assets of the enterprise. ${ }^{22}$

7 Spenke and Lier Taxation in the Netherlands (1992) 1.

18 Resident companies include subsidiaries of foreign companies and European companies (Societas Europaea or SEs) established in the Netherlands even if their management and statutory seats are located abroad.

19 See Ernst \& Young Worldwide Corporate Tax Guide (2011) 768.

20 Netherlands Income Taxes and Tax Laws http://www.worldwide-tax.com/netherlands/ dutch income tax.asp (accessed 2011-08-24). The standard corporate-tax rates have been systematically reduced over the years. For 2006 the standard corporate-tax rate was $29.6 \%$ (with 25.5\% applying to the first EUR 22 689) and for 2007 it was reduced to $27.4 \%$ (with $20 \%$ applying to the first EUR 41000 ) and 26.6\% in 2008. For 2011 the standard corporatetax rate is $25 \%$ with a $20 \%$ tax rate applying to the first EUR 200000 see Ernst \& Young Worldwide Corporate Tax Guide 768.

21 Lambooij and Peelen 2006 Bulletin for International Taxation 4.1. According to the Dutch system profits are determined on the principles of sound business practice and in a consistent manner. See also http://www.minfin.nl/en/subjects,taxation/corporate-incometax/Tax-base-and-tax-rates.html (accessed 2011-08-20).

22 See Lambooij and Peelen 2006 Bulletin for International Taxation 7. A shareholder has substantial interest if he or she directly or indirectly owns at least $5 \%$ of the shares, a specific class of shares or rights over shares. 


\section{South African corporate income tax}

Similar to the Netherlands, South Africa taxes residents on their worldwide income and non-residents on their worldwide income. ${ }^{23}$ The South African corporate-tax rate is $28 \%$. This tax rate is low compared to the United States at $35 \%,{ }^{24}$ Australia at $30 \%,{ }^{25}$ equal to the United Kingdom ${ }^{26}$ and higher than other countries such as China at $25 \%$ and The Netherlands at $25.5 \%{ }^{28}$. A difference of $2.5 \%$ in the tax rate cannot, on its own, be considered a considerable disadvantage for South Africa to attract holding companies.

\section{Capital-gains tax}

As indicated above ${ }^{29}$ in the Netherlands no distinction is made between capital gains and other income. Capital gains, like other income, are taxed at the corporate-tax rate. In this regard Lambooij and Peelen state that "[c]onsequently, dividends received and capital gains realized on the shares of a Netherlands holding company, as well as interest on loans to such a company, [are] subject to the Netherlands individual and corporate income tax at the normal rates." ${ }^{, 30}$

\section{South African capital-gains tax}

Capital-gains tax was introduced in South Africa in $2001 .^{31}$ Capital-gains tax is levied at $14 \%$ achieved through an inclusion rate of $50 \%$ of the gain into corporate income tax of $28 \%$. The Minister of finance proposed in the 2012 Budget Speech that the inclusion rate be increased to $66.6 \%$ which would result in an effective rate of $18.6 \%^{32}$

\section{Dividend tax}

The standard dividend-tax rate in the Netherlands is $25 \%$. Where the participation exemption applies, dividends paid by resident companies to other resident companies are usually tax-free. ${ }^{33}$

\footnotetext{
See definition of "gross income" in s 1 of the Income Tax Act ("the Act").

See Ernst \& Young Worldwide Corporate Tax Guide 1225.

See Ernst \& Young Worldwide Corporate Tax Guide 50.

See Ernst \& Young Worldwide Corporate Tax Guide 1177.

See Ernst \& Young Worldwide Corporate Tax Guide 197.

See Ernst \& Young Worldwide Corporate Tax Guide 133

See par 22 supra.

Lambooij and Peelen 2006 Bulletin for International Taxation 7.

Capital-gains tax was introduced by the insertion of the Eighth Schedule by s 38 of Act 5 of 2001.

32 See National Treasury Budget Review (2012) 51.

33 See Müller The Netherlands in International Tax Planning (2005) 10. See the discussion on participation exemption in par 41.
} 


\section{Controlled foreign-company provisions}

The Netherlands does not have controlled foreign-company legislation. Instead it has limited measures to prevent residents from accumulating passive income in non-resident entities. ${ }^{34}$ The participation exemption provides relief from this anti-avoidance measure. In this regard Sandler ${ }^{35}$ states as follows:

"A corporate taxpayer that holds an interest of at least 25 per cent in a nonresident company or other entity whose assets are more than 90 per cent portfolio investment must value the interest at its fair market value. Any increase or decrease in the value of the interest is included annually in the taxpayer's income unless the participation exemption applies. A special flat rate of 15 per cent applies to the first revaluation gain that results from the application of these rules."

The application of these provisions is limited in its nature. Furthermore, the participation exemption plays a major role in ensuring that holdingcompany investors are generally excluded from the application of these antiavoidance measures.

\section{South African CFC legislation}

The South African CFC legislation provides for the taxation of CFC income in the hands of the CFC's shareholders subject to exemptions, most notable of which is the genuine business-activities exemption. ${ }^{36}$ The system follows a transactional approach. Furthermore, the CFC legislation has been relaxed in line with the intention to increase South Africa's suitability to host headquarter companies. The CFC income is not attributable to South African residents that qualify as headquarter companies. ${ }^{37}$ As a result, the CFC legislation would not apply to holding companies that qualify as headquarter companies. However, the mere presence of CFC legislation may deter investors from setting up holding companies in South Africa as CFC legislation is notoriously complex.

\section{Transfer-pricing and thin-capitalization provisions}

\section{Transfer pricing}

The Dutch tax law applies transfer-pricing provisions for transactions between connected persons. Article $8 \mathrm{~b}(1)$ of the Dutch Wet op de Vennootschapsbelasting ${ }^{38}$ provides that -

4 See article 29a of the Individual Income Tax Act 1964 (IB 1964).

35 Sandler Tax Treaties and Controlled Foreign Company Legislation: Pushing the Boundaries (1998) 48

36 See s 9D of the Act.

${ }_{37} \mathrm{~S}$ 9D(2).

38 Wet op de Vennootschapsbelasting 1969. 
"Indien een lichaam, onmiddellijk of middellijk, deelneemt aan de leiding van of het toezicht op, dan wel in het kapitaal van een ander lichaam en tussen deze lichamen ter zake van hun onderlinge rechtsverhoudingen voorwaarden worden overeengekomen of opgelegd (verrekenprijzen) die afwijken van voorwaarden die in het economische verkeer door onafhankelijke partijen zouden zijn overeengekomen, wordt de winst van die lichamen bepaald alsof die laatstbedoelde voorwaarden zouden zijn overeengekomen."39

The transactions between connected persons should be documented. Such documentation should include the nature of the relationship between the entities, the description of the terms of the transactions involved and a thorough analysis of the comparability factors. ${ }^{40}$ The documentation should also establish how the prices were determined and provide a basis for determining whether the terms of the transactions would have been adopted if the parties were not connected. ${ }^{41}$ If such information is not available, the taxpayer bears the burden of proof that the prices are at arm's length, and failure to discharge this burden of proof could expose the taxpayer to noncompliance penalty charges. ${ }^{42}$ Taxpayers can use the transfer-pricing regulations ${ }^{43}$ for guidance as to the allowable pricing. These regulations are based on the Organisation for Economic Co-operation and Development (hereinafter referred to as "the OECD") transfer-pricing guidelines and merely provide the Dutch version thereof. ${ }^{44}$

39 This provision is translated into English in Netherlands Transfer Pricing Country Profile http://www.oecd.org/dataoecd/19/58/38415233.pdf (accessed 2011-02-06) as follows: "[w]here an entity participates, directly or indirectly, in the management, control or capital of another entity, and conditions are made or imposed between these entities in their commercial and financial relations (transfer prices) which differ from conditions which would be made between independent parties, the profit of these entities will be determined as if the last mentioned conditions were made".

40 See Doets and Van Dam "Transfer Pricing in the Netherlands - The 'Rules of the Road" 2006 Bulletin for International Taxation 345-346.

41 Article $8 \mathrm{~b}(3)$ of the Wet op de Vennootschapsbelasting provides as follows: "De in het eerste en tweede lid bedoelde lichamen nemen in hun administratie gegevens op waaruit blijkt op welke wijze de in dat lid bedoelde verrekenprijzen tot stand zijn gekomen en waaruit kan worden opgemaakt of er met betrekking tot de totstandgekomen verrekenprijzen sprake is van voorwaarden die in het economische verkeer door onafhankelijke partijen zouden zijn overeengekomen." The Netherlands Transfer Pricing Country Profile translates it as follows: "The entities referred to in paragraphs 1 and 2 should include in their records information that shows in which way the transfer prices referred to in paragraph 1 were established, and from which can be determined whether with respect to these transfer prices - conditions were made to which third parties would have agreed."

42 Spoelder and Bosch "Transfer Pricing Developments in the Netherlands" 2004 Bulletin for International Fiscal Documentation 159-160.

43 Besluit verrekenprijzen IFZ 2001/295.

44 See Oosterhoff "Transfer Pricing Landscape: Legislation and Guidance" in Betten (ed) The New Netherlands Transfer Pricing Regime (2002) 3-4. See also Ernst \& Young Worldwide Corporate Tax Guide 647-648. For a further discussion on the Dutch transfer-pricing system see Van Dam "Transfer Pricing Rules and Practice in the Netherlands - An Overview" 2006 Tax Management International Journal 443-458; and Kamphius, Gillis and Diakonova "Group Financial Services Companies: Tax and Transfer Pricing Policy" in Betten (ed) The New Netherlands Transfer Pricing Regime (2002) 29-58. 


\section{Thin capitalization}

Thin-capitalization rules were introduced in the Netherlands in 2004 and apply to any financial years starting on or after 1 January 2004. Under these rules interest expenses with respect to connected-party loans may be disallowed if the taxpayer is part of a group of companies. The interest will be disallowed if the debt exceeds three times the equity of the debtor company. Thus, the regime has a maximum debt-to-equity ratio of $3: 1$. However, the excess debt is considered excessive if it exceeds EUR500 000. The regime considers debt to be the difference between the taxpayer's outstanding loan liabilities and its outstanding loan receivables. ${ }^{45}$ The interest that is not deductible "must be due to a related party and is calculated as a pro-rated part of the total net interest payments of the taxpayer". ${ }^{46}$

\section{South African transfer-pricing and thin-capitalization provisions}

The South African tax law contains transfer-pricing and thin-capitalisation provisions. These provisions apply largely in line with the rules provided above. ${ }^{47}$ In addition, the transfer-pricing and thin-capitalisation provisions do not apply to financial assistance granted by a headquarter company to any foreign company. ${ }^{48}$ Furthermore the provisions do not apply to financial assistance provided to a headquarter company if the headquarter company in turn provides that financial assistance to a foreign company in which the headquarter company holds at least $20 \%$ of the equity. ${ }^{49}$ Transfer-pricing and thin-capitalization provisions are essential in a tax system to combat tax avoidance. The South African transfer-pricing and thin-capitalization rules ensure that tax avoidance is curbed, but at the same time ensure that genuine transactions in general and specifically involving headquarter companies are not adversely affected by the provisions.

\section{$37 \quad$ Foreign tax credit}

The Dutch resident taxpayers receive a credit against corporate income tax for dividends, interest and royalties from sources outside the Netherlands that are included in their taxable income. The credit applies if the dividends, interest and royalties have been subject to income tax in the source state. Furthermore, the credit is only available if the taxpayer is deemed to be the beneficial owner of the dividend, interest or royalties. The amount of the credit is the lower of the amount of tax levied by the source country and the

45 See Müller The Netherlands in International Tax Planning 86; Ernst \& Young Worldwide Corporate Tax Guide 646.

46 Müller The Netherlands in International Tax Planning 86.

47 See s 31 of the Act.

48 See s 31(4)(b) of the Act.

49 See s 31(4)(a) of the Act. 
amount of tax which would have been due under the Dutch tax law had the credit not been applicable. ${ }^{50}$

\section{The South African foreign-tax credit}

South Africa provides unilateral double-tax avoidance in the form of a tax credit for taxes payable to any sphere of government outside South Africa on income sourced outside South Africa. ${ }^{51}$ A deduction is allowed for taxes paid to spheres of government of foreign countries where the income is sourced or deemed to be sourced in South Africa. ${ }^{52}$ The tax-credit provision has been extended to apply to management and other fees. ${ }^{53}$ These provisions are a positive attribute in the South African tax system for holding companies.

\section{Group taxation}

The Netherlands corporate-tax system provides for group taxation. The system takes the form of fiscal-unity system in terms of which a Dutch holding company is allowed to file a consolidated tax return with its resident domestic subsidiaries. ${ }^{54}$ Because fiscal unity is allowed for companies that are tax-resident in the Netherlands it includes foreign incorporated subsidiaries which are tax-resident in the Netherlands due to the place of effective management being the Netherlands.

The Dutch fiscal-unity regime allows group companies to pool their profits and losses and to transfer the assets within the group without a capital-gains tax liability. Thus, losses of one subsidiary may be offset against profits of other members of the group. Furthermore, re-organizations have no direct tax consequences. ${ }^{55}$ Added to the inherent relief provided by the Dutch tax system as discussed, this fiscal-unity system further enhances the Netherlands as the ultimate holding-company regime.

\section{South African group taxation}

South Africa does not provide a group-taxation mechanism. However, grouptax relief is provided on certain transactions. The transactions which benefit from, tax relief for company groups are asset for share transactions, ${ }^{56}$ amalgamation transactions, ${ }^{57}$ intra-group transactions, ${ }^{58}$ unbundling transactions $^{59}$ and transactions relating to liquidation, winding-up and

Müller The Netherlands in International Tax Planning 155.

$\mathrm{S} 6$ quat of the Act.

$\mathrm{S}$ 6quat $(1 \mathrm{C})$ of the Act.

$\mathrm{S}$ 6quin of the Act.

See Spenke and Lier Taxation in the Netherlands 87. See also Legwaila "Intermediary Holding Companies and Group Taxation" 2010 De Jure 308.

See Spenke and Lier Taxation in the Netherlands 87-88.

$\mathrm{S} 42$ of the Act.

$S 44$ of the Act.

$S 45$ of the Act.

$S 46$ of the Act. 
deregistration of a group company. ${ }^{60}$ Where requirements for these transactions are met, the transaction does not have direct tax consequences.

\section{Exchange control}

The Netherlands law does not contain exchange-control provisions. Therefore there are no restrictions imposed on the movement of funds into and out of the Netherlands. ${ }^{61}$ South Africa on the other hand imposes exchange controls on currency and capital movements.

\section{TAX ASPECTS THAT MAKE THE NETHERLANDS POPULAR}

From a tax perspective the Netherlands is a very popular jurisdiction for multinational structures. Mainly this is due to the structure of three tax instruments, that is, the participation exemption, the double-taxation agreement network and the advance tax-rulings system. ${ }^{62}$

Dating back from the provisions of the Business Tax Act of 1893, the Dutch participation regime exempts dividend payments and capital-gains payments by subsidiary companies to holding companies from the Dutch corporate-income tax in the hands of the holding company. ${ }^{63}$ The rationale for this exemption is that profits should not be taxed twice in the corporatetax sphere and that a group of companies should be treated as one whole. ${ }^{64}$

The Netherlands has, and has for a long time had, an extensive network of DTAs which provide for a zero withholding tax for dividends, interest and royalties. By preventing double taxation these treaties stimulate trade and investment between the Netherlands and its treaty partners. The first treaty was signed in 1933 with Belgium. Currently, the Netherlands has treaties with more than 80 countries. ${ }^{65}$

The Dutch system of advance-tax rulings is a system in terms of which the taxpayer can provide the tax authorities with a planned structure prior to implementation. The taxpayer would also provide the tax authorities with the tax implications of such structure as the taxpayer understands it. If the tax authorities agree with the application of the tax code to the structure, an agreement is reached to the effect that the tax authorities would impose the tax as per the agreement. Thus, advance-tax rulings are agreements with tax authorities on how much will be taxed, given the specific method of

\footnotetext{
S 47 of the Act.

Ernst \& Young Worldwide Corporate Tax Guide 646.

See Van der Voort "Tax Planner's Guide to Holding Companies" 1998 International Tax Review http://proquest.umi.com/pqdweb?did=35146916\&Fmt=3\&clientld=27625\&RQT=309 \&VName=PQD (accessed 2011-04-14).

63 Spenke and Lier Taxation in the Netherlands 79.

64 Van Dijk, Weyzig and Murphy The Netherlands: A Tax Haven? http://somo.nl/html/ paginas/pdf/netherlands_tax_haven_2006_NL.pdf (accessed 2011-07-15).

65 See Van Dijk, Weyzig and Murphy The Netherlands: A Tax Haven? par 4.2.3.
} 
calculation. They provide upfront certainty regarding the tax consequences of planned transactions. ${ }^{66}$

In addition to the advance-tax ruling system and as an alternative to the usage of the tax treaties and the participation exemption, tax residents of the Netherlands have the added facility of the European Union ParentSubsidiary Directive. ${ }^{67}$ This specifically deals with the tax treatment of distributions by a subsidiary to its parent or holding company located in another EU-member state. It aims to promote the creation of an internal market for dividend flows between group companies incorporated within the member states of the EU.

In terms of the Parent-Subsidiary Directive the member state in which a holding company is established must refrain from taxing profitable distributions the parent company receives. As an alternative such member state must grant relief for the tax the subsidiary's member-state levies on the profit from which the dividend was distributed. On the other hand, the subsidiary's member state must exempt profits distributed by the subsidiary from withholding taxes. ${ }^{68}$

\section{The participation exemption}

\section{The nature of the participation exemption}

The participation exemption is one of the main features which make the Netherlands tax regime attractive as a means of avoiding taxation. ${ }^{69}$ Participation exemption is defined as synonymous with "affiliation privilege" which is in turn defined as "tax relief accorded to a company in respect of distributions it receives from, or (in some cases) capital gains it realizes on certain shareholdings on another company, typically where the shareholding exceeds a certain minimum percentage or acquisition cost. A minimum holding period may also be required. ${ }^{, 70}$ As its name indicates, this affiliation privilege takes the form of an exemption. ${ }^{71}$

The justification for a participation exemption is to eliminate double taxation of income when transferred to shareholders. In an accounting period, a company may pay corporate-income tax on its taxable profit which reduces the amount of post-tax profit available for a dividend distribution to shareholders. In the absence of a participation exemption, or other form of

66 See Van Dijk, Weyzig and Murphy The Netherlands: A Tax Haven? par 4.2.3; and see also Ernst \& Young Worldwide Corporate Tax Guide 636.

67 European Union Council Directive 90/435/EEC of 23 July 1990 on the common system of taxation applicable in the case of parent companies and subsidiaries of different Member States.

68 See KPMG Parent-Subsidiary Directive http://www.meijburg.com/advisory_services/euro pean_union/directives_on_direct/thedirectives/parents_and (accessed 2011-06-10).

69 See Van Dijk, Weyzig and Murphy The Netherlands: A Tax Haven? par 4.2.1.

70 IBFD International Tax Glossary definition of "participation exemption". See also Arnold and McIntyre International Tax Primer (2002) 35.

71 Internationally, the affiliation relief does not only take the form of an exemption. In certain cases the relief can also take the form of a deduction and, theoretically, a credit. 
tax relief, shareholders may be taxed on the amount of dividend income received. This results in double taxation of the same income if the dividend is paid out of profits previously taxed in the hands of the company. ${ }^{72}$

A participation exemption typically provides that certain types of dividends on income taxed in the hands of the company are not taxable in the hands of shareholders. In addition, many participation-exemption regimes provide that capital gains on shares are not taxable to the extent that the share-capital portion to which the gain relates has been held for a specified period. A participation exemption may apply to qualifying shareholdings in both foreign companies and domestic companies.

\section{Application of the Dutch participation exemption}

The Dutch participation exemption was introduced with respect to dividends as early as 1893 . This makes it one of the oldest participation-exemption regimes. Owing to its long existence, there are substantial sources and precedents in the form of case law, administrative decisions, rulings and literature. These sources make it such that most technical concerns and questions arising from specific situations can be answered with a reasonable degree of certainty. ${ }^{74}$

The Dutch participation exemption is laid out in Article 13 of the Corporate Income Tax Act of 1969 (Wet op de vennootschapsbelasting 1969). Lambooij and Portengen ${ }^{75}$ state the following:

"Under the participation exemption, qualifying elements of the profit are excluded from the taxable profit. Under this system, these elements (in general dividends, capital gains, certain costs and losses, certain currency exchange results) are included in the normal profit calculation and subsequently are excluded from the taxable profit. Therefore, in contrast to jurisdictions such as Belgium and Switzerland where the participation exemption results in a reduction of the tax payable, the Dutch system functions as a full exemption system."

The participation exemption excludes all benefits received from or realized on qualifying participations from the taxable profit of the recipient. The full exemption implies that in computing the taxable profit from the commercial profit, the full amount of the exempt elements is subtracted. The fact that the exempt elements are excluded from the calculation of the taxable profits applies not only to positive elements, but also to negative elements. Thus, profits, as positive elements, and losses and costs, as negative elements,

Spenke and Lier Taxation in the Netherlands 80.

See Arnold and McIntyre International Tax Primer 35.

74 Lambooij and Peelen 2006 Bulletin for International Taxation par 1. Bakker "Netherlands: Changes to Dutch Participation Exemption are postponed" (December 2000/January 2001) International Tax Review http://www.internationaltaxreview.com/?Page=10\&PUBID=35\& ISS=12634\&SID=468288\&SM=\&SearchStr=\%22intermediary\%20holding\%20company\%22 (accessed 2011-06-20)

75 Lambooij and Portengen Netherlands - Holding Companies par 1.3.1. 
are treated as neutral for tax purposes. The result is that losses and costs attributable to exempt elements are not deductible. ${ }^{76}$

According to the Dutch Ministry of Finance the main features of the participation exemption are as follows: ${ }^{77}$

"[a]ll benefits gained from shareholdings are exempt. In principle, the term 'benefits' covers profits and losses. Profits comprise dividends and hidden profit distributions. Exempt returns also cover the profit realised on the sale of a participation. However, losses realised are not deductible. If the value of a participation decreases as a result of losses suffered, its write-down by the parent company is in principle not deductible either. The costs associated with a shareholding are deductible. Losses arising from liquidation of a shareholding may be set off under certain conditions."

In principle if the participation exemption applies, the following elements are excluded from the taxable base: ${ }^{78}$

- All forms of dividends (whether in cash or dividends in specie) including constructive or deemed dividends. ${ }^{79}$

- Capital gains.

- Refunds of foreign tax credits and refunds of foreign withholding taxes.

- Losses on subsidiaries.

- Currency exchange results realised on instruments used to cover exchange risks on qualifying participations.

- Certain types of hybrid loan granted to qualifying subsidiaries, under such conditions that the loan de facto has the function of equity.

\section{a Qualifying participations}

The participation exemption is available to the Dutch holding company if (i) the Dutch holding company owns a minimum of $5 \%$ of the share capital of the subsidiary; (ii) the subsidiary has capital that is divided into shares; and (iii) the Dutch holding company does not hold the shares in the subsidiary as inventory. Additional conditions apply where the subsidiary is not resident in the Netherlands.

76 See the European Court of Justice's decision in Bosal Holding BV $v$ Staatssecretaris van Financiën Case C - 186/01: referred by Supreme Court of the Netherlands (Hooge Raad der Nederlanden) 11 April No 35 729. See also Lambooij and Portengen Netherlands Holding Companies par 1.3.9; Wattel "Pending Cases Filed by Dutch Courts in Direct Taxation"in Lang (ed) Recent ECJ Developments (2003) 153.

77 Corporate Income Tax, Participation Exemption http://www.minfin.nl/en/subjects,taxation/ corporate-income-tax/Participation-exemption.html (accessed 2011-09-19).

78 See Lambooij and Portengen Netherlands - Holding Companies par 1.3.9; Bakker International Tax Review.

79 This requirement goes further: it requires that the dividend should result in a benefit for the participation exemption to apply. "Purchased dividends are generally booked off from the cost price of the participation and, therefore, are generally not included in the profit and loss account. Consequently, the participation exemption does not apply, but the purchased dividends are not effectively taxed." Lambooij and Portengen Netherlands - Holding Companies par 1.3.9. 


\section{(i) Ownership of at least 5\%}

The participation exemption applies to income derived by a Dutch holding company from an investment in a subsidiary, either resident in the Netherlands or resident elsewhere. It is required that for the participation exemption to apply the Dutch holding company should hold at least $5 \%$ of the nominal paid-up share capital of such subsidiary. ${ }^{80}$

The low participation percentage makes the Netherlands a particularly attractive jurisdiction in which to base a holding company. Similar regimes in other countries require much higher percentage shareholdings if the company is to qualify for favourable tax treatment. For example, Belgium ${ }^{81}$ and Luxembourg ${ }^{82}$ require a holding of at least $10 \%$ while Switzerland $^{83}$ requires a minimum holding of $20 \%$. Furthermore, most jurisdictions require that the company be a proper holding company in the sense that its sole economic activity should be to hold shares in subsidiaries. In the Netherlands, by contrast, a company which trades but also happens to own shares in another corporate entity can be deemed a holding company for the purposes of the participation exemption rules. ${ }^{84}$

This rule is subject to three exceptions where the Dutch holding company owns less than $5 \%$ of the shares of the subsidiary. Firstly, the Dutch holding company should not hold the shares in the company declaring the dividend as a portfolio investment. In determining whether the shares are held as a portfolio investment the criterion is whether the shareholding in the foreign subsidiary has the nature of a portfolio investment from the perspective of the Netherlands holding company. What is relevant in this determination is the purpose of the shareholding in the enterprise by the Dutch holding company and not the activities of the company declaring the dividend.

"The purpose of the shareholding in the enterprise of the Netherlands holding company (or parties related to it) is relevant, rather than the activities of the subsidiary on a stand-alone basis. Elements that are relevant for determining whether [the shareholding is a portfolio investment or not] are: the size of the shareholding, the control of the shareholder over the subsidiary, the activities of the subsidiary in relation to the activities of the shareholder or related parties (the 'business link' test), the marketability of the shares, and the shareholder's expressed motives for acquiring and owning the shares. As a general test, shares are held as a portfolio investment if the holding of shares in the subsidiary is aimed at obtaining an increase in value and a yield that could be expected in the case of normal, active asset management (ie without a specific 'business link' interest).

80 Spenke and Lier Taxation in the Netherlands 80. Bakker International Tax Review.

31 Vanhaute Belgium in International Tax Planning (2008) 153.

82 See http://www.investors.oriflame.com/files/Oriflame_dividend_withholding_tax.pdf (accessed 2011-06-12).

83 Taxation in Switzerland http://www.swissprivacy.com/swiss_taxes.htm (accessed 2011-0518).

84 Netherlands: Dutch Holding Companies http://www.lowtax.net/lowtax/html/offon/ netherlands/nethold.html (accessed 2011-05-21).

85 Lambooij and Peelen 2006 Bulletin for International Taxation par 5.2.2. 
In 2009 the Dutch government announced a number of amendments to the Dutch participation-exemption regime with regards to portfolio holdings, further relaxing this exemption. ${ }^{86}$ These amendments were implemented on 1 January 2010. The new participation-exemption regime effective as per 1 January 2010 combines attractive features of the participation-exemption regime in effect prior to 1 January 2007 and the regime effective over recent years. In principle, if the subsidiary is held in the ordinary course of business and not as a portfolio investment the participation exemption would still apply in certain cases. The participation exemption would apply to portfolio investment subsidiaries if the subsidiary is subject to a sufficient level of taxation or the subsidiary's assets generally do not comprise of more than $50 \%$ of low taxed free portfolio investments.

The second exception applies where the Dutch holding company holds less than $5 \%$ of the nominal paid-up share capital and a company related to that holding company owns at least $5 \%$ of the shares in the subsidiary. Companies are generally deemed to be related in the case of a direct or indirect interest of one third or more (that is, generally direct and indirect subsidiaries, parent companies and sister companies are covered). ${ }^{88}$

Thirdly, the participation exemption would apply if the Dutch holding company does not hold the shares in the subsidiary as trading stock or inventory (that is, the holding company does not hold the shares for sale in the ordinary course of business). This requirement does not exclude the application of the participation exemption by companies that trade in shares. The exemption is available for these share traders on shares that they hold as an investment and not as trading stock.

86 Buren van Velzen Guelen "Dutch Participation Exemption" (February 2010) http://www.bvvg.nl/bvvg/detail/72/140/dutch_participation_exemption_february_2010 (accessed 2011-06-17)

87 See Buren van Velzen Guelen in fn 86.

88 The related party position is different from a group position. "In general, a group is a parent company with all its subsidiaries, provided that the subsidiary is 'controlled' by the parent company. 'Control' is generally described as the power to govern the financial and operating policies of an enterprise so as to obtain the benefits from its activities. It is presumed to exist when the parent company owns more than half of the voting rights in the subsidiary." Sunderman "Netherlands, Thin Capitalization Rules Introduced" 2004 Bulletin for International Taxation 40. Lambooij and Portengen Netherlands - Holding Companies par 1.3.2. state that "[u]nder the participation exemption rules that applied before 1 January 2007, a taxpayer with an interest below $5 \%$ of the nominal paid-in capital could nevertheless apply for the participation exemption if the participation was in line with the normal exercise of the taxpayer's enterprise, or if the acquisition of the participation served a public interest. The possibility for smaller holdings to qualify had been generally interpreted in a restrictive way by case law. In more recent case law, however, the Supreme Court had relaxed its restrictive position. In this respect, the Supreme Court decided that as long as the shareholding was not held as portfolio investment (ie for passive investment purposes) the participation would apply." Sunderman 2004 Bulletin for International Taxation par 1.3.2. See SC 14 March 2001, 95/9695, BNB 2001/210; SC 5 November 1997, VN 1997/4393 and 5 November 1997, VN 1997/4399. Participations that qualified under the pre-2007 rule prior to 31 December 2006 are deemed to meet the 5\%-shareholding threshold until 1 January 2010. See Lambooij and Portengen Netherlands - Holding Companies par 1.3.2. Bakker International Tax Review. 
Contrary to the position in other countries, the minimum shareholding in a subsidiary is not linked to a minimum holding period. ${ }^{89}$ Thus, if at the time that the investment is realized the holding company holds the required percentage, the participation exemption would apply. This makes it possible for the shareholding to be increased to coexist with the realization of the investment, after which the shareholding could be reduced to below $5 \%$ depending on the business requirements. The minimum holding period applies in the special cases where the holding company holds less than $5 \%$ and the participation exemption applies.

The participation exemption only applies to companies which are subject to normal corporate income tax. Companies that benefit from a special tax regime cannot access the participation exemption. ${ }^{90}$

\section{(ii) Subsidiary's capital divided into shares}

For the participation exemption to apply, it is required that the subsidiary should have capital that is divided into shares. This requirement exhibits a strong linkage with the $5 \%$-holding requirement. As a general rule, all corporate taxpayers in the Netherlands have capital that is divided into shares. The common forms of corporations such as the BV and Naamloze vennootschap (usually abbreviated "NV") have capital divided into shares. ${ }^{91}$

Different rules apply to specific forms that are not as common as the BV and the NV. For example, as Janssen ${ }^{92}$ states, a cooperative association

"may only be considered to have a capital divided into shares if the membership is based on a participation in the equity of the cooperative association; which is the case if the cooperative association issues shares, certificates of ownership or similar instruments that are separate and distinct from the membership interests, or where the membership interests, either with or without the shares, certificates of ownership or similar instruments, can be transferred without the prior consent of all other members."

\section{(iii) Shares not held as trading stock}

The participation exemption will apply if the Dutch holding company does not hold the shares in the subsidiary as trading stock. Shares are held as trading stock or inventory if the following conditions are met: ${ }^{93}$

89 The minimum holding period in Luxembourg and Belgium is one year.

90 Lambooij and Peelen 2006 Bulletin for International Taxation par 5.2.1. Bakker International Tax Review.

91 See http://www.ftc.nl/holland/ftctrust-legalas.html (accessed 2011-05-22). "Naamloze vennootschap (usually abbreviated NV) is the Dutch term for a public limited liability company. The company is owned by shareholders, and the company's shares are not registered to certain owners, so that they may be traded on the public stock market" http://en.wikipedia.org/wiki/Naamloze_vennootschap (accessed 2011-08-20).

92 See Janssen "Repurchase transactions in the Netherlands" 2008 International Financial Law Review http://www.iflr.com/includes/supplements/PRINT.asp?SID=515115\&ISS= 16382\&PUBID=213 (accessed 2011-08-16).

93 Lambooij and Peelen 2006 Bulletin for International Taxation par 5.2.1. 
1. The holding company holds the shares with the intention to sell those shares and the shares constitute part of the holding company's floating assets.

2. The subsidiary in which the holding company holds the shares is not, or is no longer engaged in active trade or business; and

3. The subsidiary has no assets or virtually no assets other than cash or assets that, immediately and without any significant loss, can be converted into cash.

\section{(iv) Additional requirements for foreign subsidiaries}

As mentioned earlier, the participation exemption is available for holding companies' income from investments in both resident and non-resident subsidiaries. The above requirements apply where the subsidiary is resident in the Netherlands. Where the subsidiary is a foreign company the following two additional requirements should be met for the exemption to apply: ${ }^{94}$

1. The subsidiary must be subject to tax on its profits levied in the subsidiary's resident country. This "subject to tax" requirement does not imply that there must be a tax payable. Furthermore, there is no requirement as to the level of such tax, e.g. that it should be reasonably similar to the Dutch corporate-income tax.

2. The Dutch holding company must not hold the shares in the subsidiary as a portfolio investment.

\section{South African Taxation of Dividends and Participation Exemption}

Currently, South Africa taxes companies on declaration of dividends. The tax, referred to as secondary tax on companies ("STC"), is levied on the company declaring dividends and is calculated with reference to the amount of dividends declared. ${ }^{96}$ The STC rate is $10 \% .{ }^{97}$ With effect from April 2012, the STC is replaced by a dividends-tax system in terms of which the tax will be on the shareholder receiving the dividend. Then Minister of Finance announced in the 2012 Budget Speech ${ }^{98}$ that the dividends tax will be introduced at a rate of $15 \%$ as opposed to earlier announcements that it would be at $10 \% .{ }^{99}$ The dividends-tax rate of $15 \%$ is reasonable for holding companies as compared to higher rates of dividends tax in other countries such as the United States at $30 \%{ }^{100}$ and Canada at $25 \%{ }^{101}$ Furthermore,

94 Lambooij and Peelen 2006 Bulletin for International Taxation par 5.2.2.

95 See Buren van Velzen Guelen in fn 86.

96 The tax is levied in terms of s $64 \mathrm{~B}$ of the Act.

$97 \mathrm{~S} 64 \mathrm{~B}(2)$ of the Act

98 See 2012 Budget Speech http://www.treasury.gov.za/documents/national\%20budget/2012/ speech/speech.pdf (accessed 2012-02-27). See also National Treasury Budget Review (2012) 50

99 The tax is levied in terms of $\mathrm{s} 64 \mathrm{~B}-64 \mathrm{R}$ of the Act.

100 See Ernst \& Young Worldwide Corporate Tax Guide 1225. 
qualifying dividends declared by South African headquarter companies are exempt from South African tax on dividends. ${ }^{102}$ This implies that holding companies that qualify as headquarter companies will benefit from this exemption.

\section{Advance-tax rulings}

An advance-tax ruling (hereinafter referred to as "an ATR") is a procedure in terms of which a taxpayer may obtain confirmation of the related tax consequences from the tax authorities in advance of entering into a transaction. ${ }^{103}$ The Dutch Ministry of Finance considers an ATR to be an agreement on the tax characterization of international corporate structures, such as advance certainty on the application of the participation exemption. ${ }^{104}$ The ATRs are mere interpretations of the Dutch law. They do not offer any privileges or concessions to taxpayers. ${ }^{105}$ Their purpose is to take away the uncertainty in tax areas where uncertainty exists, such as where there is little or no case law, in new areas and in areas where certain income must be reported within a certain range. ${ }^{106}$ Rulings may be issued in respect of matters relating to holding companies, future companies, royalty or intellectual property-holding companies, permanent establishments, foreign sales companies and transfer-pricing matters. ${ }^{107}$

The tax administration has a dedicated team called the ATR team or Ruling Team specifically dealing with the tax-ruling requests. The Ruling Team is located in the Rotterdam branch of the Rijnmond Tax Administration department in the inspectorate for Large Enterprises. ${ }^{108}$ The purpose of this centralization is to avoid each tax inspectorate in the different branches having to expend time and expertise discussing and agreeing on tax subjects with a major financial impact. ${ }^{109}$

101 See Ernst \& Young Worldwide Corporate Tax Guide 167.

102 See $\mathrm{s} 10(10$ (k)(ii) of the Act.

103 See the IBFD International Tax Glossary definition of "advance ruling." "In some countries an advance ruling will bind the tax authorities if the taxpayer uses the ruling. In other countries an advance such rulings cannot be obtained for hypothetical cases.

104 Kröner and Van Doorne "Legal Aspects of Tax Rulings in the Netherlands" in Campbell (ed) International Tax Planning (1995) 149. Jansen "Netherlands: New APA and ATR Policy, and Transfer Pricing Guidelines" 2001 International Tax Review http://www.international taxreview.com/?Page =10\&PUBID=35\&ISS $=12630 \& S I D=468493 \& S M=\&$ SearchStr=\%22inte rmediary\%20holding\%20company\%22 (accessed 2011-07-12).

105 Van Herksen "New and Improved: Advance Pricing Agreements" in Betten (ed) The New Netherlands Transfer Pricing Regime (2002) 109-113.

106 Advance Pricing Agreement and Advance Tax Ruling http://www.minfin.nl/en/subjects, taxation/international-aspects-of-taxation-in-the-netherlands/Advance-Pricing-Agreementand-Advance-Tax-Ruling.html (accessed 2011-08-22).

107 See Jonker and Loos "Tax Rulings in The Netherlands and The Netherlands Antilles" in Campbell (ed) International Tax Planning (1995) 151; and Jansen International Tax Review.

108 This team works in conjunction with the APA team, which is the Advance Pricing Agreement team. An "Advance Pricing Agreement entails providing advance certainty on the fiscal acceptability of the price (transfer pricing) that the Dutch group company pays to or receives from a foreign group company for receiving or delivering a service or goods". See Advance Pricing Agreement and Advance Tax Ruling.

109 See http://www.royaltytax.com/merlyn.asp?p=35 (accessed 2011-06-08). 
"The Ruling Team is under no obligation to actually issue an ATR. They have full liberty to not agree to any tax analysis made by a tax adviser on which he bases his ATR request. The Ruling Team may also decide that although they do not see fault with the tax analysis, to refuse issuing an ATR if they believe that granting one would upset the tax authorities of other countries and might cause drawbacks to the willingness of other countries to enter into tax treaties with the Netherlands or into treaty renegotiations. The Ruling Team may also decide that an ATR request was made 'to test the boundaries of tax law', cases which they do not want to bless with advance certainty to the tax payer."

The ATR is an agreement with the tax authorities and the particular taxpayer based on the given circumstances. Should the taxpayer proceed with the transaction in question with altered facts, the ruling may not be applied to such transaction. Furthermore, the ruling cannot be applied by a different taxpayer against the tax authorities even if the circumstances are identical. ${ }^{111}$ However, the previous ruling would be a persuasive instrument to command a similar tax treatment or a treatment that is suitable for the taxpayer. Correspondingly, the ruling does not form a precedent. However, it may establish an unenforceable but persuasive trend for treating certain specific transactions. A ruling is valid only for a period of no more than four years from the moment on which the activities to which it applies have commenced in the Netherlands. ${ }^{112}$

The ATR system is a very attractive tool for international investors hoping to access the participation exemption through the use of a holding company. ${ }^{113}$ Its use is relatively extensive. ${ }^{114}$ Be that as it may, there is normally no need to obtain an ATR since sufficient comfort can often be obtained from case law, policy statements and precedents. ${ }^{115}$

$110 \mathrm{http}: / /$ www.royaltytax.com/merlyn.asp?p=35 (accessed 2011-06-08). The request for the issue of an ATR is addressed to the competent tax inspector. In order to ensure the coordination of the practice, the tax inspector will submit the request to the Ruling Team for a binding advice. Where necessary, the Ruling Team consults with the relevant knowledge groups to secure a uniform policy, both in principle and in practice. Because the Ruling Team is represented in all of the relevant knowledge groups, this form of consultation can take place during the assessment process, thereby helping to ensure that the request is dealt with both swiftly and efficiently. Dutch Policy for Advance Tax Rulings; See http://www.tax-consultants-international.com/read/Dutch policy_for_advance tax $r$ (accessed 2011-06-11).

111 See Jansen International Tax Review.

112 Kröner and Van Doorne International Tax Planning 153.

113 See Jansen International Tax Review. For more on advance-tax rulings see Van Dam and Jacobs "Advance Tax Rulings in Betten (ed) The New Netherlands Transfer Pricing Regime (2002) 119-130

114 By way of comparison, Shelton applauds the Dutch advance-tax rulings system by stating that "although Denmark has a system of advance rulings, it is not nearly as useful as the Dutch system" (Shelton "Denmark Squares up for Holding Battle" (December 1998/January 1999) International Tax Review http://www.internationaltaxreview.com/?Page=10\&PUBID= 35\&ISS $=12655 \& S I D=468670 \& S M=\& S e a r c h S t r=\% 22$ intermediary $\% 20$ holding\%20 company \%22 (accessed 2011-07-13).

115 Lambooij and Peelen 2006 Bulletin for International Taxation par 5.2.2. 


\section{South African advance-tax rulings}

The South African tax regime provides for the facility of tax rulings. ${ }^{116}$ Tax rulings can take the form of a binding class ruling, ${ }^{117}$ binding general ruling, ${ }^{118}$ binding private ruling ${ }^{119}$ and non-binding private opinion. ${ }^{120}$

\section{Treaty network}

The purpose of a tax treaty is the avoidance of double taxation. According to Holmes, ${ }^{121}$ "[f]rom their inception the raison d'être of DTAs has been the avoidance of double taxation". ${ }^{12}$ The solution to the problem of double taxation involves taxing income only once and that leads to consideration of which country will have the taxing right. The determination of which country will have the taxing right is customarily contained in the DTAs.

The Dutch treaties provide persons to whom the treaties apply with additional treaty benefits in two forms, namely, the high number of treaties and the elimination of certain taxes payable by Dutch residents.

Generally, Dutch DTAs contain articles that award the taxing rights on dividends, interest and royalties to the Netherlands or to the other contracting state. The Dutch treaties often result in dividend-withholding tax on dividends paid to the Netherlands holding company being reduced to zero. This is a special feature of the Dutch tax treaties emanating from the Dutch government's policy on tax treaties. In most countries' treaties the dividend withholding tax is usually set at a rate between $5 \%$ and $15 \% .{ }^{123}$ The Dutch treaties also reduce the tax rates for dividends paid by a Dutch holding company to its parent from $25 \%$ to a maximum of $15 \%$.

Treaties also eliminate the withholding tax on interest and limit withholding tax on royalties to a maximum of $15 \%$ on interest and royalties paid to the Netherlands. On the other hand, in terms of the Dutch domestic law withholding tax from the Netherlands is always zero on interest and royalties, irrespective of the target country. A combination of these attributes establishes the Netherlands as an ideal jurisdiction to host a variety of companies in multinational structures. As Van Dijk, Weyzig and Murphy observe, "[t]his makes it especially attractive for foreign companies to establish a conduit company in The Netherlands to route royalty, licence or

\footnotetext{
S 76B of the Act.

7 Definition of "binding-class ruling" in s 76B of the Act.

118 Definition of "binding-general ruling" in s 76B of the Act.

119 Definition of "binding-private ruling" in s 76B of the Act.

120 Definition of "non-binding private opinion" in s 76B of the Act.

121 Holmes International Tax Policy and Double Tax Treaties - An Introduction to Principles and Application (2007) 54.

122 Holmes International Tax Policy and Double Tax Treaties 54. Raison d'être is a phrase borrowed from French where it means simply "reason for being"; English usage comes to suggest a degree of rationalization, as the claimed reason for the existence of something or someone; see http://tiscali.co.uk/reference/dictionaries/difficultwords/data/d0010875.html (accessed 2011-07-13).

123 Van Dijk, Weyzig and Murphy The Netherlands: A Tax Haven? par 4.2.2.
} 
patent payments, tax international markets and intermediate in groupfinancing structures." 124

The Netherlands has concluded treaties with over 80 countries. This is a favourable treaty network for a vast number of investors from all over the world. Quite importantly, the Netherlands has concluded treaties with the world's financial strongholds, including, the United States of America, the United Kingdom, China, Germany, Japan and France. Save for France and the United Kingdom (with about 90 and 100 treaties respectively), the Netherlands has more treaties than any of these countries.

\section{South African tax-treaty network}

South Africa has more than 70 tax treaties and is in the process of entering with treaties with more countries. Furthermore, some of the treaties currently in force are renegotiated. ${ }^{125}$ This is a fairly considerable tax-treaty network covering most developing countries from which investment in the form of holding companies can be expected.

\section{Parent-subsidiary directive}

The Parent-Subsidiary Directive ("the directive") is a multilateral agreement between the European Union ("EU") member states contained in the European Union Council Directives. ${ }^{126}$ It specifically deals with the taxtreatment distributions by a subsidiary to its parent or holding company located in a foreign EU member state. It aims to promote the creation of an internal market for dividend flows between group companies incorporated in the EU. Dividend distributions to non-EU shareholders do not qualify for the parent-subsidiary directive treatment. ${ }^{1}$

Since the directive was adopted in July 1990 it has had the most immediate effect on cross-border business transactions in Europe. It has proved to be of great help to countries with poor treaty networks in the EU, either because they are considered to be tax havens ${ }^{128}$ or because of their limited cross-border business relations. ${ }^{129}$ Without a tax treaty, investors in these countries had to rely on the unilateral tax relief provided by their home countries. $^{130}$ The directive deals with these issues that were previously exclusively dealt with in bilateral tax treaties.

24 Ibid.

125 See http://www.sars.co.za/home.asp?pid=3919 (accessed 2011-10-17).

126 EU Council Directive (90/435/EEC) of 23 July 1990. See Schonewille "Some Questions on the Parent-Subsidiary Directive and the Merger Directive" (1992) International Tax Review 13-20.

127 Peters "National Report Netherlands" in Lang, Herdin and Hofbaner (eds) WTO and Direct Taxation (2005) 506.

128 An example of a country with few tax treaties because it is considered to be tax haven is Cyprus.

129 Bulgaria and Estonia are examples of limited cross-border relations countries.

130 Thömmes and Nakhai Introduction to the Parent-Subsidiary Directive http://online2.ibfd. org/data/ectl/cm/CM-CH-06.doc.p0005.html (accessed 2011-06-29). 
The directive is based on two basic premises contained in its preamble. Firstly, when the holding company receives a distribution of profits from the subsidiary, the state of the holding company should refrain from taxing such profits or tax such profits while authorizing the holding company to deduct from the amount of tax due that fraction of the corporation tax paid by the subsidiary which relates to those profits. ${ }^{131}$ Secondly, the profits which a subsidiary distributes to its holding company should be exempt from withholding tax in the hands of the holding company. ${ }^{132}$

The status of a holding company to which the directive applies is attributed to a company resident in a member state which has a minimum holding of $10 \%$ in the capital of a company of another state. ${ }^{133}$ This minimum holding requirement was reduced from $15 \%$ on 1 January 2009. For the directive to apply -

(i) the holding company and the subsidiary must be companies whose capital can be divided into shares, for example, BV or NV; ${ }^{134}$

(ii) the subsidiary should not, under the terms of a bilateral tax treaty concluded with a third state, be resident for tax purposes outside the $\mathrm{EU} ;{ }^{135}$ and

(iii) the holding company and the subsidiary must be subject to corporate income tax. ${ }^{136}$

The directive allows member states to set minimum periods for which shares must be held. However, such period may not exceed two years. Under this provision, the Netherlands prescribed a minimum period of one year. This requirement was abolished in January $2007 . .^{137}$ The abolition of the one-year minimum holding period was to align the application of the directive with the participation exemption. Certain investors' circumstances would have been better suited to apply the participation exemption over the directive, thus placing EU investors in an adverse tax position where there is no tax treaty between the Netherlands and the investor's home country.

Owing to its multilateral nature, the directive provides broader tax relief than bilateral treaties. As Thömmes and Nakhai observe,

Preamble and Article 6 of the EU Council Directive.

32 Ibid. The exemption from withholding tax on the subsidiary is directed at ensuring fiscal neutrality. Germany and Greece, by reason of the particular nature of their corporate-tax systems, and Portugal for budgetary reasons are authorized to temporarily maintain a withholding tax.

133 Article 3 of the EU Council Directive. Prior to 1 January 2007 the minimum holding percentage was $20 \%$ and was reduced to $15 \%$ on that date. The gradual reduction of the minimum holding percentage was brought by the amendment to the directive by Council Directive 2003/123/EC of 22 December 2003 to improve the directive's practicality.

134 Article 2(1)(a) of the EU Council Directive.

135 Article 2(1)(b) of the EU Council Directive.

136 Article 2(1)(c) of the EU Council Directive. See also Parent-Subsidiary Directive http://www.meijburg.com/advisory_services/european_union/directives_on_direct/the_directi ves/parents_and (accessed 2011-07-13).

137 Corporate Income Tax Act of 2007. 
"even in a tax treaty situation, the benefits of the Parent-Subsidiary Directive significantly outweigh the benefits granted by bilateral tax treaties. On the one hand, the criteria under the Parent-Subsidiary Directive are uniform for all Member States (even though some countries were granted special transition periods and certain details of the application may vary in different countries). On the other hand, the benefits granted by the Parent-Subsidiary Directive are usually more far-reaching than the ones granted by individual tax treaties which usually only provide for a reduction of withholding tax but not for a complete elimination of withholding taxes. Last but not least, the fact that the application and interpretation of the Parent-Subsidiary Directive by the individual Member States is subject to the jurisprudence of the European Court of Justice (ECJ) proved to be another significant advantage for taxpayers over the past years".

Because the EC law prevails over bilateral agreements between individual member states, the directive overrides a bilateral tax treaty if and to the extent that provisions in that treaty which differ from those of the directive are less favourable to the companies affected than the directive's position. Conversely, if a bilateral treaty grants more benefits than the directive or requires less stringent conditions to be met than the directive in order to obtain the same benefits under both regimes, the bilateral treaty provisions cannot be objected to as an infringement of EC law. ${ }^{139}$ The directive's benefits may be limited under the member state's anti-tax abuse legislation. ${ }^{140}$

For purposes of the directive, "withholding tax" does not cover an advance payment or prepayment of corporation tax to the member state of the subsidiary which is made in connection with a distribution of profits to its holding company. ${ }^{141}$ Furthermore, the directive does not affect the application of domestic or provisions contained in any agreement designed to eliminate or lessen economic double taxation, in particular provisions relating to the payment of tax credits to the recipient of dividends. ${ }^{142}$

\section{Comparison between the directive and the participation exemption}

The directive and the participation exemption apply in the same circumstances and in relation to the same nature of transactions. However, the directive is limited to member countries. In relation to the distributions by Dutch companies, there is no dividend-withholding tax in both cases. The requirements for the exemption from the dividend-withholding tax are the same.

With regard to distributions to Dutch companies, even prior to the implementation of the directive the Netherlands already refrained from taxing such distributions by using the participation exemption. The requirements under the directive and the participation exemption are the same. The

\footnotetext{
Thömmes and Nakhai par 4 (see fn 130 above).

Thömmes and Nakhai par 5 (see fn 130 above).

Article 2.2 of the EU Council Directive.

Article 7(1) of the EU Council Directive.

Article 7(2) of the EU Council Directive.
} 
difference exists with regard to the minimum holding percentage, which is $5 \%$ for the participation exemption and $10 \%$ for the directive. It has to be noted that this difference has been marginally reduced since prior to 2006, when it was $25 \%$.

\section{South African directive equivalent}

As stated above the directive and the participation exemption apply in the same circumstances and in relation to the same nature of transactions. Furthermore, for Dutch tax purposes, the directive is limited to member countries. Thus, the South African participation exemption achieves the same purpose at a larger scale than the Directive, making the directive not additionally beneficial to the Dutch system. As a result the Directive on its own does not make the Netherlands more tax efficient for holding companies than South Africa.

\section{PROPOSALS FOR THE DUTCH CORPORATE TAX REFORM}

The Dutch State Secretary of Finance issued a consultation document on 15 June 2009 containing proposals for changes to the Dutch corporate tax regime. ${ }^{143}$ If implemented, this regime would allow foreign operations to be leveraged from and through the Netherlands without incurring significant Dutch tax burden. The main changes that would enhance the position of the Netherlands as a holding location are the following:

- Interest-box regime - Interest income would be taxed at an effective rate of $5 \%$. Interest expenditure would be equally deducted at $5 \%$. The regime would be mandatory to intragroup interest income and expenditure.

- Participation-exemption regime - The participation exemption is to be applicable if the participation is not held as a portfolio investment. The intention of the taxpayer is decisive in determining whether the holding is portfolio or not.

- Carry back of losses - It is proposed that the tax-loss carry back period be extended from 1 year to 3 years.

- Limitation of interest deductions - In the Netherlands it is possible to deduct interest expenditure on financing of qualifying participations while the income on such participations is exempt under the participation exemption. It is proposed that the thin-capitalization rules be abolished

${ }^{143}$ Ernst \& Young Dutch Government Issues Consultation Document on Tax Reform http://www.ey.com/Publication/vwLUAssets/N_Dutch_International_Tax_Alert,_June_12_20 09/\$FILE/N Dutch\%20International (accessed 2011-07-11); Ruijten and De Vries Dutch State Secretary Issues Discussion Paper Regarding Tax Treatment of Interest and Relaxation of Participation Exemption Rules http://www.bakernet.com/BakerNet/Resources/ Publications/Recent+Publications/AmsterdamDiscussionPaperTaxCAJun09.htm (accessed 2011-07-11). 
and the transaction-based anti-avoidance rules be expanded to address this anomaly. ${ }^{144}$

\section{CONCLUSION}

As has been seen in this analysis of the aspects of the Dutch tax system that apply to holding companies, the Netherlands is a very suitable tax jurisdiction for the hosting of a holding company. It allows access to tax relief to a wide range of investors with different countries of origin. The Dutch corporate-and tax-law systems are flexible. Furthermore, as has been observed, the corporate law is currently under review with a view to making it even more flexible.

Entities whose identity is the same as those of a conventional company can access the tax attributes of the Dutch system that make it popular. These forms are common and investors are familiar with their nature, operation, uses and the risks they involve.

The holding company would access the benefits of the participation exemption and the directive where the group operates within the EU as soon as it is formed, due to the fact that there is no minimum holding period in the Netherlands, on application of either the participation exemption or the directive. This is essential for a group where the group has accumulated profits that should be distributed but could be eroded by the tax system of the ultimate holding company.

The Netherlands holding-company regime indisputably provides an ideal environment for investors to set up holding companies to perform their functions in the Netherlands without the tax regime eroding the finance base of the group.

In international tax planning, perception of a country's investment environment tends to be more important that actual economic, regulatory and tax framework. The lack of exchange-control provisions is a major boost to the Dutch attempts at encouraging the presence of holding-company structures. On the other hand, the presence of such provisions could deter potential investors from investing in South Africa. This is not necessarily because in effect exchange controls might restrict remittances by a particular company, but because the perception is that there is no certainty that the company will be able to remit funds at a time that it wishes to. The fact that the Netherlands does not have controlled foreign-company legislation labeled as such, conceals the fact that some transactions and structures may be subject to anti-avoidance measures that are literally tantamount to controlled foreign-company provisions. The impact of the Dutch measures to prevent residents from accumulating passive income in non-resident entities is targeted at the same income as controlled foreign-company legislation provisions are targeted at.

144 See Ruijten and De Vries fn 143 above; and Ernst \& Young Dutch Government Issues Consultation Document on Tax Reform. 
The Dutch government went to great lengths to create publicity around the fact that it attempts to be a suitable jurisdiction for hosting holding companies. As with Mauritius, by so doing, the Netherlands managed to advertise the special features in the regime that are designed to attract holding companies to its shores. ${ }^{145}$ South Africa should follow suit and advertise the new regime for headquarter companies aggressively.

The standard dividend-tax rate in the Netherlands is $25 \%$. This is higher than the $10 \%$ rate applicable in South Africa. In this regard, the ParentSubsidiary Directive is, to a very large extent, a duplication of the participation exemption. Its effect would be more pronounced where local tax laws do not provide for the participation exemption or where the participation exemption applies by virtue of a treaty. As a result, the availability of the participation exemption does not make the Netherlands any more attractive than South Africa. The fact that the Southern African Development Community and the African Union do not as yet provide for a multilateral agreement that could include a facility such as the Parent-Subsidiary Directive does not place South Africa in a disadvantageous position because the South African tax law provides for the participation exemption. ${ }^{146}$

Thin-capitalization and transfer-pricing provisions are essential antiavoidance instruments in international transactions. Their presence in a tax regime has proved in the Netherlands not to have an effect on holding companies, especially if their impact on back-to-back loans is neutralized. Furthermore, the Dutch and the South African provisions are similar. Also similar is the relief on taxes on foreign-sourced income.

The South African government should constantly upgrade the law as far as headquarter companies are concerned in order to improve its accessibility. This will also improve the international perception of the keenness of the government to attract foreign investment. One of the positive externalities of such amendments would be to provide the much needed publicity as news of the changes to legislation will remain a talking point amongst investors and advisors.

In the end, what separates the Netherlands from South Africa on taxation of holding companies is controlled foreign-company legislation, exchange control and group taxation. The South African government needs to address the application of these instruments adequately in order to allay fears of uncertainty that are raised by these instruments. If that is not done, these instruments may deter investors even in cases where they would not adversely apply to their structures or instruments. The reality is that regardless of the extent of the relaxation of the CFC legislation and exchange-control provisions, risk-averse investors will remain deterred by the presence of these instruments and the expected influx of investors will remain suppressed.

\footnotetext{
145 See Legwaila Tax Treatment of Holding Companies in Mauritius 15.

$146 \mathrm{~S} 10 \mathrm{~B}$ of the Income Tax Act 58 of 1962.
} 